\title{
Towards mandatory
digital literacy in Quebec's
Schools? \\ Towards mandatory
digital literacy in Quebec's
Schools? \\ Towards mandatory
digital literacy in Quebec's
Schools?
}

Thierry Karsenti

Université du Québec à Montréal

doi:10.10.18162/fp.2018.a161

\section{CHRONIQUE • Technologies en éducation}

\section{Background}

Technology at school: are we progressing or digressing? Is there too much or too little? Are we for it or against it? There are no easy answers to these questions, especially in light of the growing distaste for learning as students continue to lose interest and drop out, according to many recent studies (see Ryan \&Deci, 2016 ${ }^{1}$ ). Technology use at school is an issue that angers and divides teachers, pedagogical counsellors, school administrators, and parents. Few education topics have sparked such heated debates as this one, according to the recent book Le désastre de l'école numérique: plaidoyer pour une école sans écrans ${ }^{2}$ (The disaster of the digital school: a plea for a screenless school). Twenty or thirty years ago, we wondered whether technology would wield impacts on academic performance. Would it bring the hoped-for benefits of more learning, better learning, different learning, and enthusiasm for learning? From the standpoint of 2016, this question may have been poorly formulated. That is, taking sides on this particular issue- to be for or against technology in education-may have sent us down the wrong path. In 2016, in Québec and around the world, it is high time to try another route. We should drop this toothless debate and focus on the role that technology plays in education. Instead of pondering whether or not technology has a place in education, we could start thinking about how technology can help improve teaching, learning, and skills development. "How" is the operative word here. Despite the lingering disputes, the time to advocate "for" or "against" is long past. 
We begin this article with an overview of recent studies on technology in education. We then attempt to show that, in a world where technology, issues, and cultures are changing rapidly, digital literacy should be a mandatory subject in elementary and high school.

\section{Does technology really impact academic performance?}

With the publication in September 2015 of the main conclusions of an OECD report ${ }^{3}$ called Students, Computers and Learning: Making the Connection, combined with the conclusions of John Hattie's ${ }^{4}$ meta-analyses of the impacts of technology on education, revealing a supposedly weak effect on student performance, ${ }^{5}$ many continue to ask themselves if technology really has a place in education. First, we should look at some of the drawbacks of these two studies, which have persuaded so many to re-question the use of technology for education.

Broadly speaking, the OECD report reveals that the more that students use new forms of technology at school, the lower their academic performance. This might seem logical, in the sense that it is difficult to demonstrate a direct association between effective technology use and technology purchases. However, the report also illustrates the largely unvoiced argument that the pedagogical purposes of the technology need to be considered, and that it is not enough to focus solely on access to computer equipment. In several studies (see Karsenti \& Collin, 20136), we could not conclude a direct association between technology and student performance. Technology certainly has vast educational potential, but in practice, it is what the teachers do with it that counts, as well as what teachers can get their students to do with it. At the end of the day, how technology is used makes all the difference. Furthermore, the OECD reminds us that educational technology is here to stay, but that the digital shift can only be effective if teachers are properly trained to use technology to good advantage, and if they show their students how to use technology to learn.

Turning to John Hattie's $\left(2008^{7}\right)$ recommendations, almost half the studies he consulted date from the aughts (years 2000 to 2010), and some are from as far back as 1977. Given the forms of technology that were available at the time (e.g., before Google, FaceBook, YouTube, and Wikipedia, to name a very few), this drastically limits the scientific amalgamation.

That said, Hattie himself recognized that the technological impact on student performance was liable to grow enormously, particularly if:

- Technology could enable a variety of teaching strategies

- Teachers could be trained how to use technology for teaching and learning

- Technology could be used to expand learning opportunities

- Technology could give students more control over their learning

- Technology could increase opportunities for collaborative and peer learning

- $\quad$ Feedback mechanisms could be optimized

- Technology could boost student motivation. 
We contend that instead of viewing educational technology as a panacea or the Holy Grail, we should view it as a useful tool with high educational potential. A more recent large-scale study on the impact of technology on education ${ }^{8}$ concludes that technology realizes its greatest potential when every student has a personal device, when every student is taught how to use technology for learning, and when teachers are equipped with the skills they need to use technology for effective teaching. As with any tools, the impact on student performance is directly dependent on how the technology is used. Therefore, for technology to positively contribute to the academic success of all students, the teacher's role is important as never before.

\section{Overview of the situation Québec}

At a time when other Canadian provinces are introducing coding at school, ${ }^{9}$ when some countries have included the game Minecraft in the school curriculum, ${ }^{10}$ and when other so-called conservative countries require students to write their texts on a computer using word processing software, ${ }^{11}$ what is the state of educational technology in schools in the province of Québec, Canada?

In the 1970s, Québec went through what we might call an audiovisual crisis: equipment was fragile, cumbersome, and costly, and there were incompatibility issues. These appeared to be the underlying reasons for the overall failure of the audiovisual component of teaching practices, and why this component was shunted to the side. Simply put, teachers were unfamiliar with the equipment and had no clue what to do with it. Against this background, the first computers were quietly introduced into schools in the late 1970s. In 1981, Québec's education department (le ministère de l'Éducation du Québec - MES) set up its first ministerial committee on the use of computers in education, with a mandate to coordinate work on computer-assisted education and to prepare a development plan for promising applications. In 1983, the MES implemented a large-scale initiative to bring microcomputers (PCs) and microcomputing into the education system (Plan de développement de la micro-informatique scolaire). The aim was to teach computer science (also called microcomputing) courses at school, with a focus on understanding and using PCs and software.

With the advent of the new Plan d'action numérique en éducation of the Quebec Government (Quebec educational technology plan), the educational role of technology veered in a major new direction. It was no longer a question of teaching computer science per se. The idea became to promote the integration of technology into teaching practices across all school subjects. Technology progressed from the status of a learning objective to a learning medium. However, the passing of this reform eclipsed the use of technology for teaching purposes. At the same time, computer knowledge became a transversal competency (also called a cross-curricular competency), without which teachers could not be considered truly in command of their teaching practice. This state of affairs presupposed that all students, because they used many forms of technology in their daily lives, were capable of using technology to learn. In hindsight, many studies have shown that this is not necessarily the case. On the contrary, computer use by young people, even frequent or daily use, does not automatically transfer to educational use. In addition, studies have shown that each generation of youth develops its unique uses of technology according to momentary interests, social circles, ethnocultural backgrounds, and so on. Moreover, there is nothing to indicate that they all have the skills they need to use technology for learning. 


\section{CHBONIOLIE}

\section{Mandatory teaching of digital literacy in elementary and high school}

Although we would very much like technology to contribute to student performance, we must first establish it as a subject in itself, commonly called digital literacy. This new subject would enable students to develop a global digital learning culture and would prepare them to use technology to learn a variety of subjects, develop further competencies outside of school (e.g., computer science and other skills), engage in lifelong learning, and learn in an informed, responsible manner. On condition that digital literacy is designated as a subject in itself, technology can make a real difference in education. Nevertheless, making digital literacy a mandatory subject does not mean sweeping away the old curriculum and starting from zero. For our education systems, the first challenge in technology integration would be to strike an optimal balance between preserving certain traditional methods that have been included in the teaching arsenal for centuries and taking advantage of the new opportunities offered by computer-assisted methods. To do so, we should not limit ourselves to a simply utilitarian vision. Instead, we should carefully identify potential educational transformations and outcomes. Finally, it is vital for this technological advance to be aligned with our pedagogical principles and with teaching strategies that embrace change and innovation. It is less about learning how to use technology and more about learning how to use technology in order to teach better.

\section{Notes}

1 Ryan, R. M. and Deci, E. L. (2016). Facilitating and Hindering Motivation, Learning, and Well-being in schools. Research and Observations from Self-Determination Theory. In K. Wentzel et D. B. Miele (Eds.), Handbook of Motivation at School, 2nd Edition (pp. 96-119). New York : Routledge.

2 Bihouix, P. et Mauvilly, K. (2016). Le désastre de l'école numérique: plaidoyer pour une école sans écrans. Paris : Seuil.

3 http://www.oecd.org/publications/students-computers-and-learning-9789264239555-en.htm

4 Hattie, J. (2009). Visible learning: A synthesis of over 800 meta-analyses relating to achievement. New York: Routledge.

5 Hattie (2009) found a positive impact of 0.18 on academic achievement.

6 Karsenti, T. et Collin, S. (2013). Avantages et défis inhérents à l'usage des ordinateurs portables au primaire et au secondaire. Éducation et francophonie, 41(1), 94-122.

7 Hattie, J. (2008). Visible learning: A synthesis of over 800 meta-analyses relating to achievement. routledge.

8 Zheng, B., Warschauer, M., Lin, C.-H., \& Chang, C. (2016). Learning in One-to-One Laptop Environments: A Meta-Analysis and Research Synthesis. Review of Educational Research, 20(10), pp. 1-33. DOI: $10.3102 / 0034654316628645$

9 http://www.theglobeandmail.com/technology/bc-government-adds-computer-coding-to-school-curriculum/ article28234097/

10 http://www.theregister.co.uk/2013/01/15/swedish_school_minecraft_lessons/

11 http://www.corestandards.org/ELA-Literacy/W/4/ 